\title{
Orofaciodigital syndrome type 9
}

INSERM

\section{Source}

INSERM. (1999). Orphanet: an online rare disease and orphan drug data base.

Orofaciodigital syndrome type 9. ORPHA:141007

Oral-facial-digital syndrome, type 9 is characterized by highly arched palate with bifid tongue and bilateral supernumerary lower canines, hamartomatous tongue, multiple frenula, hypertelorism, telecanthus, strabismus, broad and/or bifid nasal tip, short stature, bifid halluces, forked metatarsal, poly- and syndactyly, mild intellectual deficit and specific retinal abnormalities (bilateral optic disc coloboma and retinal dysplasia with partial detachment). 